\title{
HOPE ELIZABETH HOPPS
}

\author{
(1926-1988)
}

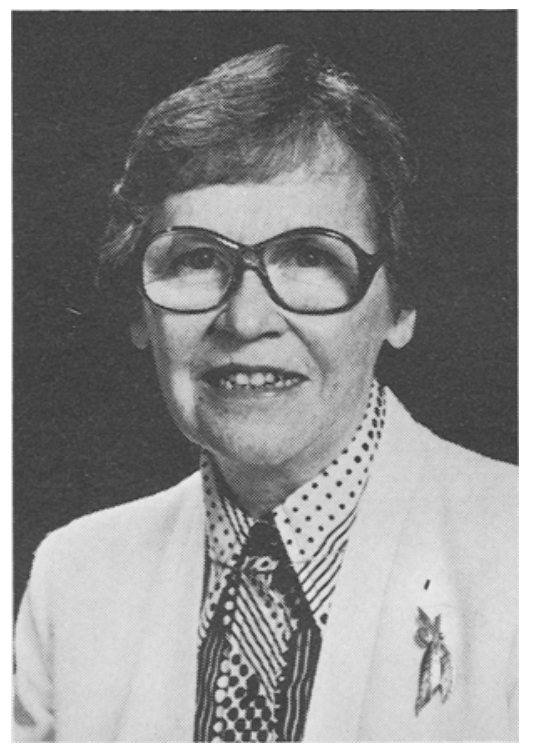

The Tissue Culture Association has lost a distinguished member in Hope E. Hopps, who after a valiant struggle, died of cancer on November 7, 1988. She is survived by her husband George, whom she married in 1952.

Hope was born in West Warwick, Rhode Island, on June 15, 1926. She received a B.S. in bacteriology from the University of Rhode Island in 1947 and worked as a graduate assistant in avian viral diseases at the URI Agricultural Research Station. During her graduate studies at the University of Maryland, she received a National Research Council Scholarship and her M.S. degree in 1950.

Hope was Senior Bacteriologist at the Garfield Memorial Hospital in Washington, D.C. From 1951-56 she worked in the Department of Virus and Rickettsial Diseases of the Walter Reed Army Institute of Research; from 1956-60 at the National Institute of Allergy and Infectious Diseases; and from 1960-66 in the Laboratory of Viral and Rickettsial Diseases of the Division of Biologics Standards of the National Institutes of Health. From 1966-72 she was a Research Biologist and Chief of the Immunology Section of the Laboratory of Viral Immunology in the Division of Biologics Standards. From 1972-81 she was Assistant to the Director of the Bureau of Biologics, a division of the Food and Drug Administration. In 1981, Hope "retired", but the word had little meaning for her. She returned to the FDA in
1982-83 as Acting Associate Director for Program Development and Operations. During her second "retirement", in 1983, she served as a consultant and guest worker at the Center for Drugs and Biologics of the FDA.

Among Hope's notable scientific contributions were development of a continuous grivet monkey kidney cell line, which was critical for determining the safety of live poliovirus vaccines, and her discovery of the ability of rickettsiae to produce interferon. She was the co-developer of the first subhuman primate cell lines suitable for vaccine production and of the first practical procedure for wide-scale evaluation of rubella immunity. Her work contributed to the development of live rubella virus vaccines and evaluation of their safety and effectiveness (1966-70). She received two U.S. patents for discoveries related to vaccine development. Hope was a strong believer in basic research as a solution to practical problems. Her efforts to support risky projects and young investigators aided a number of individuals who are now renowned cell biologists.

Hope's numerous honors included associate membership of the Armed Forces Epidemiology Board's Commission on Rickettsial Diseases (1963-77); National President of Graduate Women in Science (1972-73); and recipient of the FDA's Award of Merit (1977). She also served as a member of the US-USSR Science Exchange delegation to review research 
on influenza therapy and the use of interferon (1973-74). Hope's interests were by no means limited to basic science, FDA issues and the TCA. She was an avid art, music and people lover.

Within the TCA, Hope was President of the Washington, D.C. Chapter (1974-75), National Vice-President (1978-80), and a member of the Council and intermittently the Executive Board from 1974 to 1988 . Hope was elected an Honorary TCA member in 1987.

During her tenure as Chairman of the Publications Committee, she initiated a new format and name change for In Vitro Cellular \& Developmental Biology. Hope cheerfully volunteered her services for myriads of TCA activities, always penetrated to the heart of complicated issues, and was a unifying voice of moderation when issues became heated. Hope served on the Board of Directors of the W. Alton Jones Cell Science Center (1979-81). She was instrumental in the evolution of the Center into an independent world-class basic research center in cell and molecular biology.

Hope's modus operandi was such that usually only her closest colleagues were aware of her tireless optimism and activities. Her contributions reach far beyond her mortality and serve as an example to all of us.

We offer our heartfelt condolences to her husband George. We sorely miss her.

Charity W aymouth and The Editors 